POLITICS AND TECHNOLOGY 
Also by John Street

REBEL ROCK: The Politics of Popular Music

DECIDING FACTORS IN BRITISH POLITICS: A Case Study

Approach (with John Greenaway and Steve Smith) 


\section{Politics and Technology}

John Street

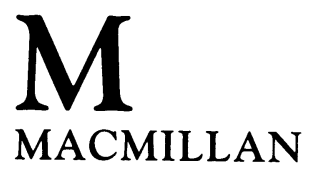


All rights reserved. No reproduction, copy or transmission of this publication may be made without written permission.

No paragraph of this publication may be reproduced, copied or transmitted save with written permission or in accordance with the provisions of the Copyright, Designs and Patents Act 1988, or under the terms of any licence permitting limited copying issued by the Copyright Licensing Agency, 90 Tottenham Court Road, London W1P 9HE.

Any person who does any unauthorised act in relation to this publication may be liable to criminal prosecution and civil claims for damages.

First published 1992 by

THE MACMILLAN PRESS LTD

Houndmills, Basingstoke, Hampshire RG21 2XS

and London

Companies and representatives

throughout the world

ISBN 978-0-333-53498-4

ISBN 978-1-349-22274-2 (eB ook)

DOI 10.1007/978-1-349-22274-2

A catalogue record for this book is available from the British Library

Copy-edited and typeset by Povey-Edmondson

Okehampton and Rochdale, England 
For my parents, Margaret and Peter Street 


\section{Contents}

Acknowledgements viii

1 A Few Technicalities 1

2 Political Change and Technical Change 14

3 The State and Technology 46

4 The Politics of Science 70

5 The Political Effects of Technology 92

6 Choosing Technologies 115

7 The Green Solution 138

8 The Technical Fix 157

9 Democracy and Technology 177

$\begin{array}{ll}\text { Bibliography } & 198\end{array}$

$\begin{array}{ll}\text { Index } & 209\end{array}$ 


\section{Acknowledgements}

This book started life as an undergraduate course, and I owe a considerable debt to all the students who helped formulate the ideas and arguments which follow. My thanks also go to my colleagues at the University of East Anglia: Albert Weale, Tim O'Riordan, Ray Kemp, Alan Cottey and John Greenaway, and friends elsewhere, in particular Mike Stephens, Tim Giles and Ian Forbes. My publisher Steven Kennedy has not only been patient, he has done much to improve my efforts, as has my editor, Keith Povey. Matt Cliffe and Andrew Webster kindly read a draft manuscript, and helped me to clarify my thoughts. Steve Smith has far exceeded the obligations of a good friend and colleague; he has combined criticism with encouragement, and I am very grateful for both. And finally, my thanks to Alex, Jack and Marian Brandon for all sorts of things which reduced the miseries of writing a book and enhanced the pleasures.

JohN STREeT 